\title{
Laboratory experiments in the ecological work on rockpool animals with special notes on the ostracod Heterocypris salinus
}

\author{
BJÖRN GANNING
}

\author{
Askölaboratoriet, Department of Zoology, University of Stockholm, Stockholm, Sreden
}

EXTRAIT: Laboratoire expérimentaux aux recherches écologiques sur les animaux des flaques d'eau en particulier sur l'ostracode Heterocypris salinus. Les organismes colonisant les flaques vivent dans des conditions très variables et souvent extrêmes au point de vue physico-chimique. Pour bien déterminer les particularités écologiques de ces organismes il est nécessaire d'effectuer des prospections aussi bien que des études de laboratoire. Pour que les études faites en laboratoire soient adéquates, les variations annuelles et diurnes des facteurs écologiques doivent être connus. Il importe également de mettre les cas extrêmes bien en évidence. Dans cette étude nous présentons un certain nombre d'expériences sur l'ostracode Heterocypris salinus BRADY, faites au laboratoire et fondées sur des prélèvements effectués tout le long du jour dans une flaque très riche en organismes de cette espèce, située dans le nord de la Baltique. En même temps que la distribution des organismes furent observées et notées, pendant les 24 heures, des variations de salinité, de température, de $\mathrm{pH}$, de teneur en oxygén et d'illumination. Comme on pouvait s'y attendre, ces facteurs-ci présentent de grandes fluctuations, à l'exception de la salinité qui ne varie pas. Dans la nuit 101 ostracodes furent retrouvés dans des algues des couches superficielles tandis que, de jour, 6 individus seulement furent récoltés au même niveau et dans la même quantité d'algues. Afin d'expliquer la variation que font ressortir ces chiffres, nous avons procédé à des expériences de préférence et de résistance en soumettant $H$. salinus à des varations de facteurs mentionnés. Ces expériences montrent que $H$. salinus est de façon marquée négativement phototactique et très résistant dans une eau faiblement oxygénée, sans être pour cela en état de choisir activement entre saturation faible ou saturation élevée (34 et $410 \%$ de saturation respectivement). La température et la salinité sont par contre des facteurs dont la force d'attraction est en rapport étroit avec l'intensité. $H$. salinus préfère de manière active $15^{\circ} \mathrm{C}$ à $22^{\circ} \mathrm{C}$ et $6 \%$ à 20,12 ou $1 \% \mathrm{~S}$. Ces résultats peuvent contribuer à expliquer les variations de distribution relevées, mais il faut également prendre en considération l'éffet convergent des différents facteurs, effet qui se réalise différemment selon l'intensité de chaque facteur. $H$. salinus réagit fortement à l'illumination et à la température, probablement aussi à la teneur en oxygéne et en gaz carbonique, tandis que, dans le type examiné de flaques, la salinité est de moindre importance. Les résultats présentés indiquent que $H$. salinus est bien préadapté au milieu des flaques, tout comme Gammarus duebeni, autre organisme, et mieux connu, colonisant le même biotope.

\section{INTRODUCTION}

Organisms living in rockpools and tidepools, those natural aquaria of the seashore, are often exposed to varying environmental conditions both throughout the 
year and during day and night cycles. Descriptions of such variations have never been summed up but detailed data are given by many authors (AMBLER \& CHAPMAN 1950, Biebl 1937, Davy de Virville 1934, 1935, Feldman \& Davy de Virville 1933, Fisher 1929, Igarashi 1959, 1960, Issel 1914, Lami 1941, Legendre 1923, 1930, Lindberg 1944, McGregor 1965, Naylor \& SlinN 1958, Nordenskiöld 1900, Pyefinch 1943, Reuter 1961, Stephenson, Zoond \& Eyre 1934, Vacelet 1959, 1963 , and others). In these investigations certain characteristics concerning the distribution of rockpool organisms are given as results of, e. g., the resistance capacity to different environmental factors, and interrelations between different organisms. Except for the works of Gersbacher \& Denison (1930), Lagerspetz (1955, 1958), Kinne (1959), Matutani (1961), Ranade (1957), Rees (1941) and a few others, very little has been done experimentally on rockpool organisms and their responses to their environment. This lack of pertinent publications has been one of the reasons for conducting the present investigation.

The rockpool fauna and flora is very poor in regard to the number of species present, but often rich in regard to the number of specimens both of macro- and microscopic organisms. This fact facilitates ecological work, and experiments can be carried out on large populations which are quite homogenous with respect to their age distribution.

Laboratory tests should be carried out on the basis of results obtained in the field. To be able to test the animals pertinently it is necessary therefore, to know both normal and extreme annual and diurnal intensities of the most affective environmental factors. Comprehensive information on ecological reactions can be obtained from resistance tests, where the survival rates of organisms exposed to different environmental biotic and abiotic factors are studied, as well as from preference tests - in this case alternative tests - where the animals are offered two different intensities of one factor, all others being kept constant according to principles discussed by GaNNING $8 x$ WULFF (1966).

\section{METHODS}

Measuring the factors has been done in the following way. Illumination was determined by the use of a selen photocell (Trilux-Gossen). Oxygen was recorded by a precision galvanic cell oxygen analyser prepared after MANCY, OKun \& REILLEY (1962). Temperatures in the laboratory were measured with small mercury thermometers. Salinities were determined with an immersion cell connected with a Wheatstone bridge, earphone and buzzer (for reasons discussed by Jansson 1962). Continuous field temperatures were obtained by using a galvanic point recorder with six resistance thermometers. A battery operated portable $\mathrm{pH}$ measuring instrument (Philips PR 9401) equipped with Ingold glass and reference electrodes gave hydrogen-ion values. Filtered sea water and distilled water were mixed in order to obtain different salinities. 


\section{THE ENVIRONMENT}

The microhabital environmental variations depend on many factors such as the microclimate, the topography of the pool, the amount of organisms, flower plants, algae, animals, and organic substances. Figure 1 shows the outlines of a rockpool located immediately above the sea level. The size of the pool is $3 \times 12 \mathrm{~m}$, its depth

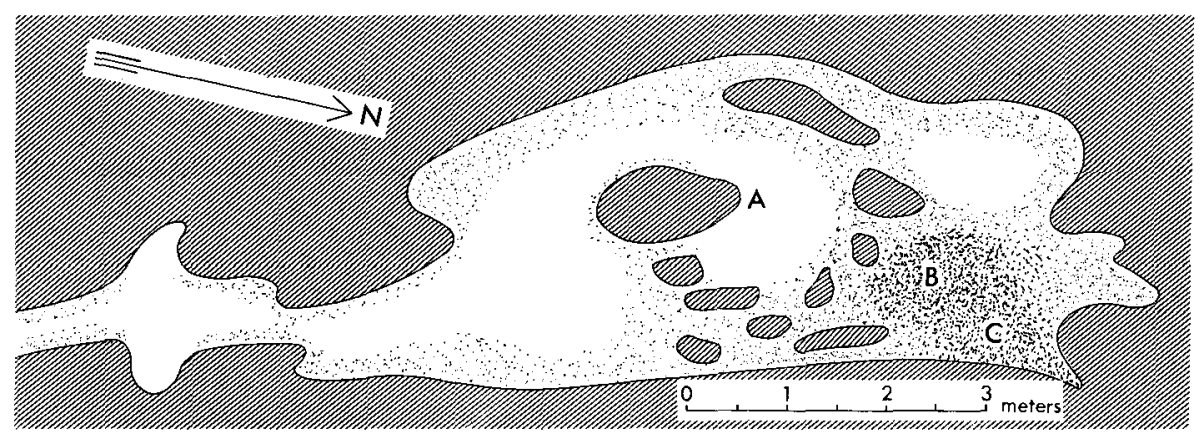

Fig. 1: Outlines of the investigated pool at Vrångskär, Askö, Sweden. Environmental measureat different depths. Air temperature and light recordings are given when extreme mals were sampled. The dots indicate algae in the surface water

Table 1

Maximum and minimum values for temperature, $\mathrm{pH}$ and oxygen concentration and saturation, at different depths. Air temperature and light recordings are given when extreme (July 21 to 22, 1966, in pool illustrated in Fig. 1)

\begin{tabular}{|c|c|c|c|c|c|c|}
\hline Factor & $\begin{array}{l}\text { Depth } \\
\text { in } \mathrm{cm}\end{array}$ & Minimum value & $\begin{array}{l}\text { Time } \\
\text { of day }\end{array}$ & Maximum value & $\begin{array}{l}\text { Time } \\
\text { of day }\end{array}$ & $\begin{array}{l}\text { Date } \\
\text { for } \\
\text { max. } \\
\text { value }\end{array}$ \\
\hline temperature & 2 & $18,9^{\circ} \mathrm{C}$ & 04 & $30,5^{\circ} \mathrm{C}$ & 16 & 22.7 \\
\hline $\mathrm{pH}^{2}$ & 2 & 8,5 & 04 & 9,8 & $15-17$ & 21.7 \\
\hline oxygen & 2 & $0,5 \mathrm{mg} \mathrm{O} / 1=5,5 \%$ & 04 & $16,6 \mathrm{mg} \mathrm{O}_{2} / 1=214 \%$ & 13 & 22.7 \\
\hline temperature & 40 & $18,9^{\circ} \mathrm{C}$ & $04-07$ & $21,8^{\circ} \mathrm{C}$ & 19 & 22.7 \\
\hline $\mathrm{pH}^{2}$ & 40 & 8,5 & 04 & 9,3 & 21 & 21.7 \\
\hline oxygen & $\begin{array}{l}40 \\
\text { algae }\end{array}$ & $0,06 \mathrm{mg} \mathrm{O} / 1=0,7 \%$ & 04 & $6,2 \mathrm{mg} \mathrm{O} / 1=75 \%$ & 19 & 21.7 \\
\hline temperature & $1 \mathrm{~cm}$ & $18,1^{\circ} \mathrm{C}$ & 04 & $28,0^{\circ} \mathrm{C}$ & 132 & $21 . / 22.7$ \\
\hline $\mathrm{pH}^{1}$ & $1 \mathrm{~cm}$ & 8,6 & 04 & 10,4 & 13 & 21.7 \\
\hline oxygen & $1 \mathrm{~cm} 0$ & $0,53 \mathrm{mg} \mathrm{O}_{2} / 1=5,8 \%$ & 04 & $27,0 \mathrm{mg} \mathrm{O}_{2} / 1=342 \%$ & 14 & 21.7 \\
\hline air temperature & $100 \mathrm{~cm}$ & $\quad 18,5^{\circ} \mathrm{C}$ & 03 & $26,5^{\circ} \mathrm{C}$ & 13 & 21.7 \\
\hline light & surface & $o \operatorname{lux}$ & 23 & 68,000 lux & 10 & 22.7 \\
\hline
\end{tabular}

$0.5 \mathrm{~m}$. Its walls and bottom were covered with luxuriant Enteromorpha sp. The pool volume was filled to about $60 \%$ with free floating Cladophora glomerata and rooted tufts of Enteromorpha. A $12 \mathrm{~m}$ long, $0.2 \mathrm{~m}$ broad crevice in the SE end may bring sea water into the pool when the sea is rolling. 
Vertical measurements have been made at intervals of $10 \mathrm{~cm}$. Figure 2 illustrates the fluctuations of temperature, hydrogen-ion concentration, oxygen content, and illuminance during 30 hours of unusually warm and sunny weather at the end of July 1966. Recordings from depths of 2.20 and $40 \mathrm{~cm}$ respectively in the open water at A (Fig. 1) are presented. In the great masses of floating Cladopbora (at B) another measurement point was established; illuminance, air temperature well above the ground and salinity, which was $6.8 \% \mathrm{~S}$ all the time, were recorded.

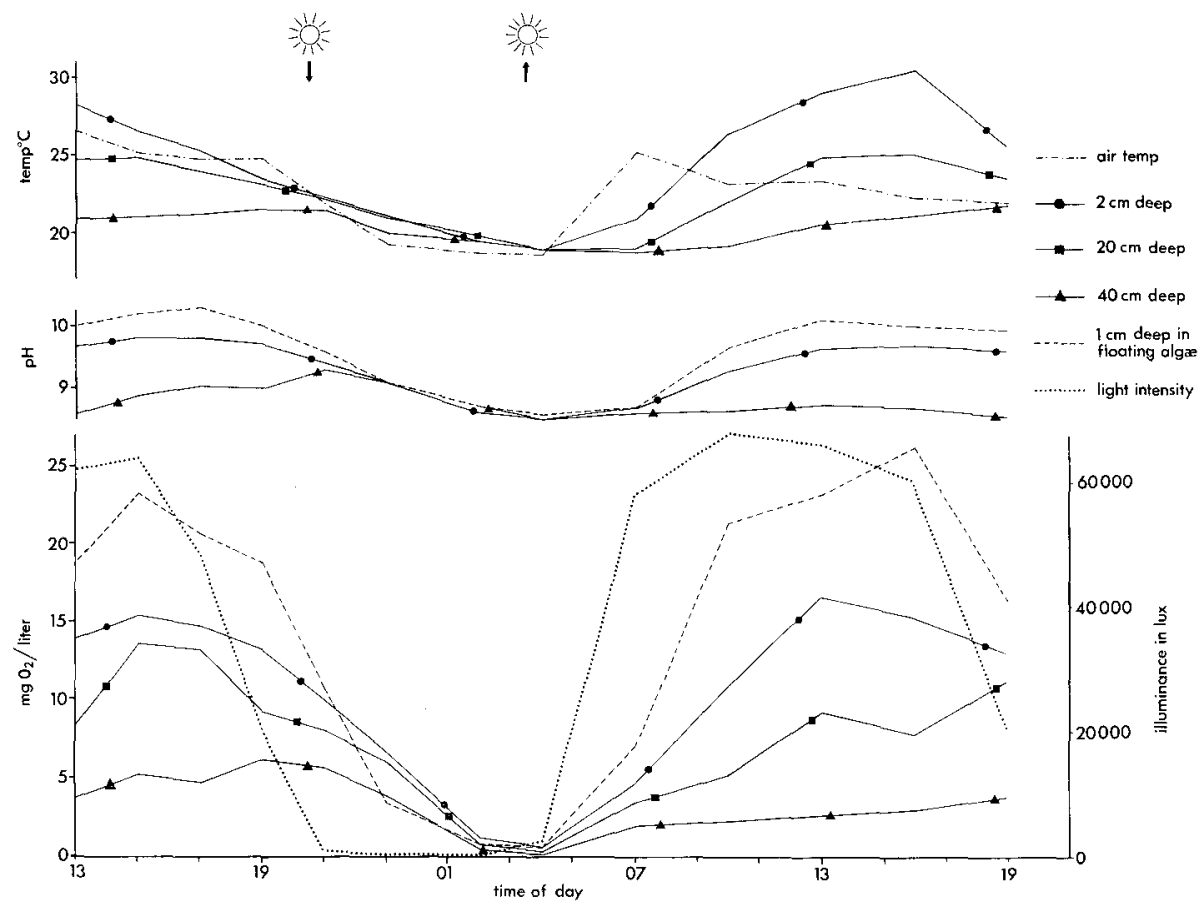

Fig. 2: Diurnal measurements in the rockpool at Vrångskär Askö (July 21 to 22, 1966). Vertical: intensities of temperature, $\mathrm{pH}$, oxygen concentration and illuminance; horizontal: time of day

At $20 \mathrm{~cm}$ depth the values obtained were well between those from depths of ? and $40 \mathrm{~cm}$. The extreme intensities measured at the last two points and the Cladophora floats are plotted in Table 1. For comparison the following figures from the Cladophora belt of the open sea may be mentioned: 14 to 15 of July 1964, in the algal belt $42 \mathrm{~cm}$ below surface, at high water, maximum and minimum values for temperature, oxygen and illuminance ranged from $17.6^{\circ}$ to $14.9^{\circ} \mathrm{C}, 119 \%$ to $68 \%$ oxygen saturation, and 60.000 to 0 lux. The recordings were made at noon and $4 \mathrm{o}^{\prime} \mathrm{clock}$ in the morning respectively (A. M. JANsson, personal communication). The fluctuations in the pool are enormous compared to those of the open sea shore.

Many other recordings have been made but the ones mentioned represent some of the most extreme ones ever made, and hence are of great interest for the problems to be discussed here. 


\section{FIELD DISTRIBUTION}

It has been of special interest in the present work to explain differences in the field distribution between day and night as observed on adults of the ostracod Heterocypris salinus. Samples obtained at two different times, 04:00 and 16:00, on July 22, 1966, are presented in Table 2. The samples were taken at $C$ (Fig. 1) in the surface

Table 2

Day and night abundances of Heterocypris salinus in surface waters with Cladophoraglomerata (July 22, 1966)

\begin{tabular}{ccc|}
\hline Time of day & 04 & 16 \\
\hline numbers of animals per $0,1 \mathrm{~g}$ algae dryweight & 101 & 6 \\
\hline
\end{tabular}

centimeter of the floating Cladophora. The ostracods rise to the surface in the night and move downwards during the day. Based on these field investigations, laboratory experiments on reactions to light, oxygen, carbon dioxide, temperature, and salinity were carried out.

\section{REACTIONS TO LIGHT}

Heterocypris salinus was tested for its light reactions in a simple alternative chamber consisting of a petri dish of $10 \mathrm{~cm}$ diameter, divided into 4 quadrants, 2 painted white and 2 black. A lid with only 2 black quadrants was fitted in above the

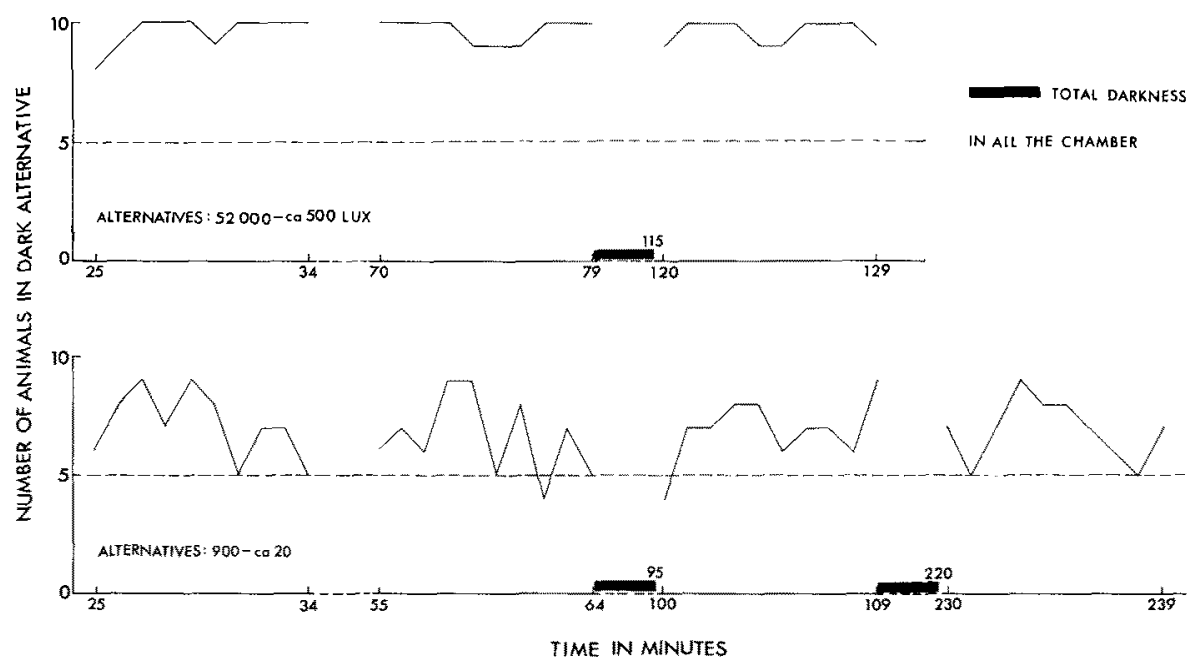

Fig. 3: Light alternative tests with Heterocypris salinus at 52.000-500 lux and 900-20 lux; $\mathrm{n}=10$ 
two black quadrants of the petri dish. This half covered box was filled with water of $10 \% \mathrm{~S}$ and was exposed to light of different intensity. 10 animals at a time were tested in the chamber. A very striking negative phototactic reaction can be seen when the alternatives are 52.000 lux and about 500 lux (Fig. 3); these conditions correspond to bright sunshine and twilight at about sunset or sunrise respectively. When the animals enter the bright zone from the dark one, they stop immediately and "tumble" back again. When offered the alternatives of 900 lux and about 20 lux (corresponding to twilight time and half an hour later in the evening or earlier in the morning) the reactions are weaker but there is still a preference for the dark side though this is not so conspicuous (Fig. 3). Dark intervals do not change the general picture of the experiment. This might be a sufficient explanation of their great abundance in the surface waters during the night time. It was, however, considered necessary to study the reactions to other variables before drawing definite conclusions.

\section{REACTIONS TO OXYGEN}

Fox \& TAYLOR (1955) have shown that many lake inhabitants survive longer in hypo- than in hyperoxygenated or even in $100 \%$ aerated waters. In order to find out whether the very low night oxygen tensions in the deep parts of the investigated pool cause upward movements and, especially whether the great surface hypersaturation in the daytime forces the animals down, several tests were carried out. Resistance experiments at different salinities performed in darkness using the technique of Fox (diffusing nitrogen, air and oxygen) gave the results shown in Figure 4. This figure also illustrates the results of a test with low oxygen tension induced by Enteromorphatufts due to their consumption of oxygen when kept dark. The experimental arrangements are seen in Figure 5. In this way, $\mathrm{CO}_{2}$ instead of $\mathrm{N}_{2}$ substitutes $\mathrm{O}_{2}$. The experiment was carried out at 21 to $24^{\circ} \mathrm{C}$ with water volumes of $200 \mathrm{ml}$ in a dark cupboard. As can be seen from Figure 4, the animals survive longest in water hyposaturated either by nitrogen diffusion or algal metabolism. Hyposaturation gives LD 50 values of 10 to 11 days except for the combinations $0.5 \% \mathrm{~S}$ nitrogen (3 days) and $15 \% \mathrm{~S}$ algae (4 days). Hypersaturation gives death rates which seem to be independent of salinity with LD 50 values occurring after 4 to 5 days. $100 \%$ saturation causes the death of half the animals after 6 to 8 days.

\section{Table 3}

Mean values of at least 12 readings of oxygen concentration and saturation in test series diffusing nitrogen, air or oxygen, and in a test series with oxygen consuming algae tufts. The last series does not include the first 24 hours

\begin{tabular}{|c|c|c|c|c|c|c|c|c|}
\hline \multirow{2}{*}{$\begin{array}{l}\text { Oxygen } \\
\text { content } \\
\% 0 \\
\text { Salinity }\end{array}$} & \multicolumn{2}{|c|}{ Nitrogen } & \multicolumn{2}{|c|}{ Air } & \multicolumn{2}{|c|}{ Oxygen } & \multicolumn{2}{|c|}{ Algae } \\
\hline & $\mathrm{mg} \mathrm{O}_{2} / 1$ & $0 / 0$ satur. & $\mathrm{mg} \mathrm{O} / 1$ & $\% / 0$ satur. & $\mathrm{mg} \mathrm{O}_{2} / 1$ & $\emptyset / 0$ satur. & $\mathrm{mg} \mathrm{O} / 1$ & $0 / 0$ satur. \\
\hline 0,5 & 1,5 & 18 & 8,8 & 104 & 30,2 & 350 & 2,3 & 26 \\
\hline 5 & 2,1 & 25 & 8,4 & 101 & 28,5 & 338 & 2,5 & 29 \\
\hline 15 & 1,9 & 22 & 8,4 & 107 & 28,0 & 353 & 2,5 & 31 \\
\hline
\end{tabular}


The oxygen consumption obtained in test series with Enteromorpha is plotted at the bottom of Figure 4. During one day, seven $5 \mathrm{~cm}$ long Enteromorpha tufts lowered the oxygen tension to values between 2.6 and $3.2 \mathrm{mg} \mathrm{O} /$ /liter (31-41\% saturation) and in 4 days to values between 2.0 and $2.4 \mathrm{mg} \mathrm{O} / 1$ (22-28\% saturation). Subsequently the oxygen disappeared very slowly during the experiment. By using gas and diffusers a steady state can be attained after 15 minutes of vigorous bubbling into
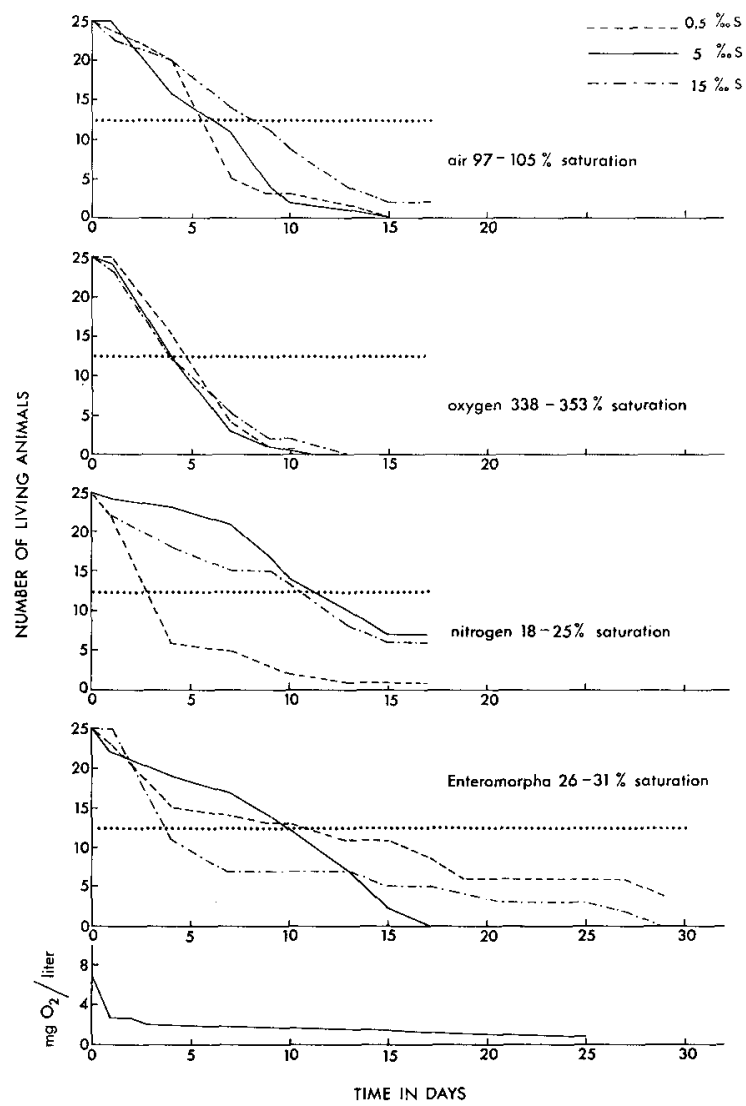

Fig. 4: Resistance tests with Heterocypris salinus to different oxygen saturations obtained by gas diffusion or oxygen absorption at 3 different salinities. At the bottom the oxygen absorption by Enteromorpha tufts in darkness is plotted

this water volume. To maintain this state, only slow diffusion rates are needed. Mean values of at least 12 readings on $\mathrm{mg} \mathrm{O}_{2} /$ liter and percent oxygen saturation from the different test solutions are shown in Table 3 . In the algal column the mean values do not include the first 24 hours of the experiment.

Reactions on different oxygen tensions were tested in an alternative chamber described by GANNING \& WulfF (1966). Some results are presented in Figure 6. The animals were considerably motile throughout the experiment. However, clear pre- 
ference was found for neither $34 \%$ nor $410 \%$ oxygen saturation. Evidently the animals do not react actively to different oxygen tensions; this finding is in contrast to results obtained from another rockpool crustacean, namely Daphnia magna (GANNING \& WULFF 1966).

High carbon dioxide concentrations, which must be assumed to occur in the rockpool at night, especially in its deep parts, are presumably harmful to the ostracod.

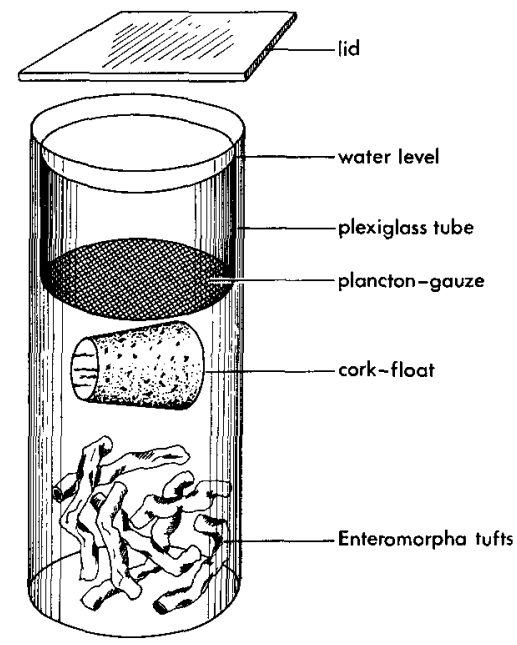

Fig. 5: Experimental arrangements for obtaining low oxygen tensions by consumption of Enteromorpba tufts. The animals are kept on the plankton gauze of the inserted plexiglass tube

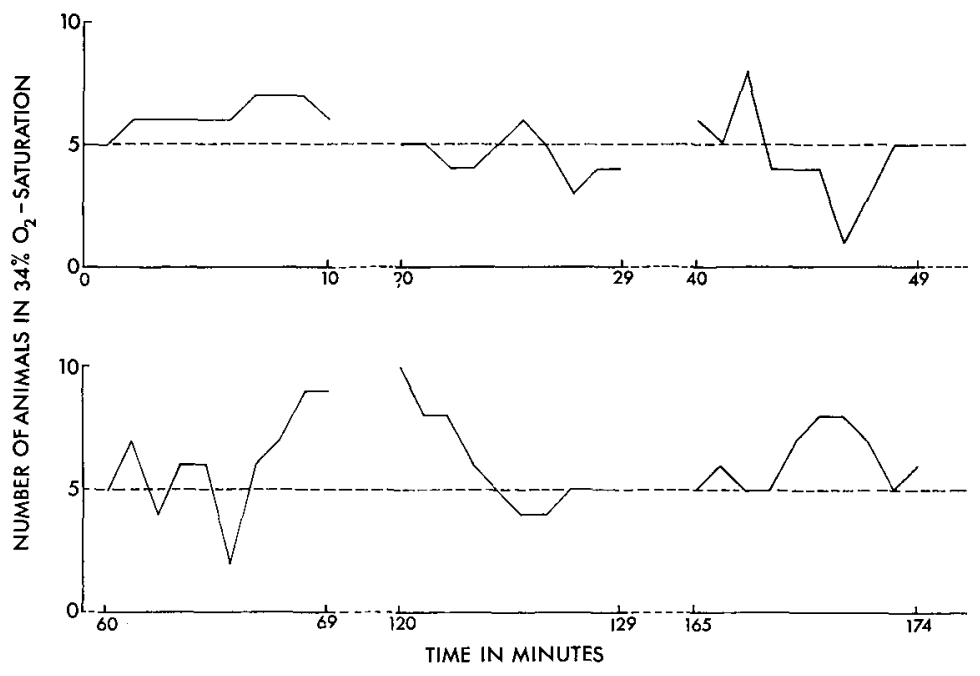

ALTERNATIVES: $34-410 \% \mathrm{O}_{2}$-SATURATION

Fig. 6: Oxygen alternative test with Heterocypris salinus at 34 and $410 \%$ oxygen saturation; $\mathrm{n}=10$ 
When put into water of $6 \% \mathrm{~S}$ diffused by $\mathrm{CO}_{2}$ the animals become comatose within 15 minutes; however, when the animals are brought back into normal conditions they recover quite fast, even after 210 minutes of gas exposition. Changes from negative to positive light reaction were not found in the ostracod. UBRIG (1952) found such changes, for example, in Daphnia.

Perhaps a successive change in the $\mathrm{O}_{2} / \mathrm{CO}_{2}$ relation can force the animals to move up or down. The resistance experiments showed that during the 24 hours cycle $H$. salinus is in no immediate danger. For an individual living in near optimum conditions of salinity (cf. later) respiration is certainly no problem, as demonstrated by KINNE (1952) for the rockpool living Gammarus duebeni.

\section{REACTIONS TO TEMPERATURE}

Several tests on resistance and developmental abilities in different temperaturesalinity combinations have been carried out; their results will be published later. Only one experiment will be discussed here to exemplify a case of preference for one of two quite different temperatures representing night and day values respectively. The

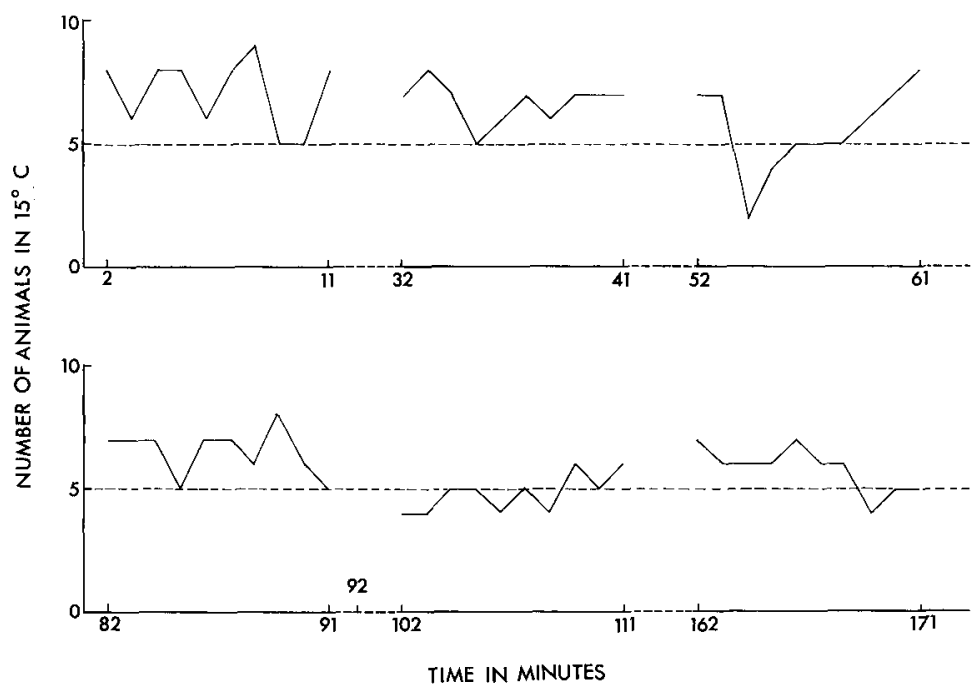

ALTERNATIVES: $15-22^{\circ} \mathrm{C}$

Fig. 7: Temperature alternative test with Heterocypris salinus at $15^{\circ}$ and $22^{\circ}$. Inversion of alternatives after 92 minutes; $\mathrm{n}=10$

experiment was carried out at $15^{\circ} \mathrm{C}$ in a constant temperature room, representing one alternative. A gradient of 22.5 to $21.8^{\circ} \mathrm{C}\left(22^{\circ} \mathrm{C}\right.$ in Fig. 7) maintained by an electric heater was the other alternative. The preference for $15^{\circ} \mathrm{C}$ was small, but quite distinct. After 92 minutes the alternatives changed sides. Very slowly the preference for 
the lower temperature was established again. This result, obtained on individuals brought into the laboratory from the earlier described pool with a temperature fluctuation of about 10 degrees in its surface waters during the day, indicates the importance of the temperature factor in forcing the ostracods down in the pool during the period of daytime high surface temperatures. At night the homogenous water temperature represents no barrier to upward movements.

The gradient zone in the alternative chamber was passed without any discernable reaction. In the whole chamber locomotory activity was very high all the time. This result indicates that natural temperature layers create no severe problems for the ostracod Heterocypris salinus.

In contrast it may be mentioned that eggbearing 99 of the rockpool harpacticid Nitocra spinipes have a distinct preferendum for $24^{\circ} \mathrm{C}$ when offered $24^{\circ}$ and $20^{\circ} \mathrm{C}$ in the alternative chamber, as shown by WuLFF (unpublished). This preference is not changed if the test individuals are kept up to a week at other temperatures. N. spinipes is very abundant in the Enteromorpha zone even during the high day temperatures and has evidently no diurnal movements.

\section{SALINITY PREFERENCES}

The resistance of Heterocypris salinus to different salinities was discussed by Ganning (1966). There is a slight optimum at $10 \% \mathrm{~S}$, but, within very wide ranges, i. e. 1 to $20 \%$, the test individuals survived almost as well. When offered for free choices different salinities the following results were obtained (Fig. 8). The preference for $6 \%$ is very distinct if $20 \%$ is the alternative. The same results are obtained after 5 days of acclimation to 20\%. Also, when offering a choice between 6 and $12 \%$, there is undoubtedly a preference for $6 \%$. When the ostracod is exposed to 6 and $1 \%$ respectively, the reactions are quite divergent. During the first hour of the experiment most of the test individuals are found in $6 \%$ but later on, the distribution is 50 to $50 \%$.

From these results it can be concluded that there is a relatively stable adaptation to the most common biotope salinity of this population of $H$. salinus. The same situation has been shown to exist in Gammarus duebeni which shows preferences for 0.5 to $6.3 \% \mathrm{~S}$ when caught in about $6 \% \mathrm{~S}$ (unpublished, own results). The habitat salinity is, in the course of one or several days, of little importance unless heavy rainfalls occur. $6.8 \% \mathrm{~S}$ was recorded in the rockpool under observation in all water depths.

The effect of gradual salinity changes during long periods of time has been studied in adaptation experiments; their results will be published later.

KLIE (1938) established that $H$. salinus is a very eurytopic form; this is true for many rockpool organisms. In experimental work on such organisms it would be of interest to test not only LD 50 values and preferences but also the absolute resistance to environmental factors and fluctuations. Certainly only one or a couple of survivors are sufficient to repopulate the rockpool biotope.

The present investigation confirms that Heterocypris salinus is well pre-adapted to the fluctuating rockpool conditions, just like the well-known Gammarus duebeni. 


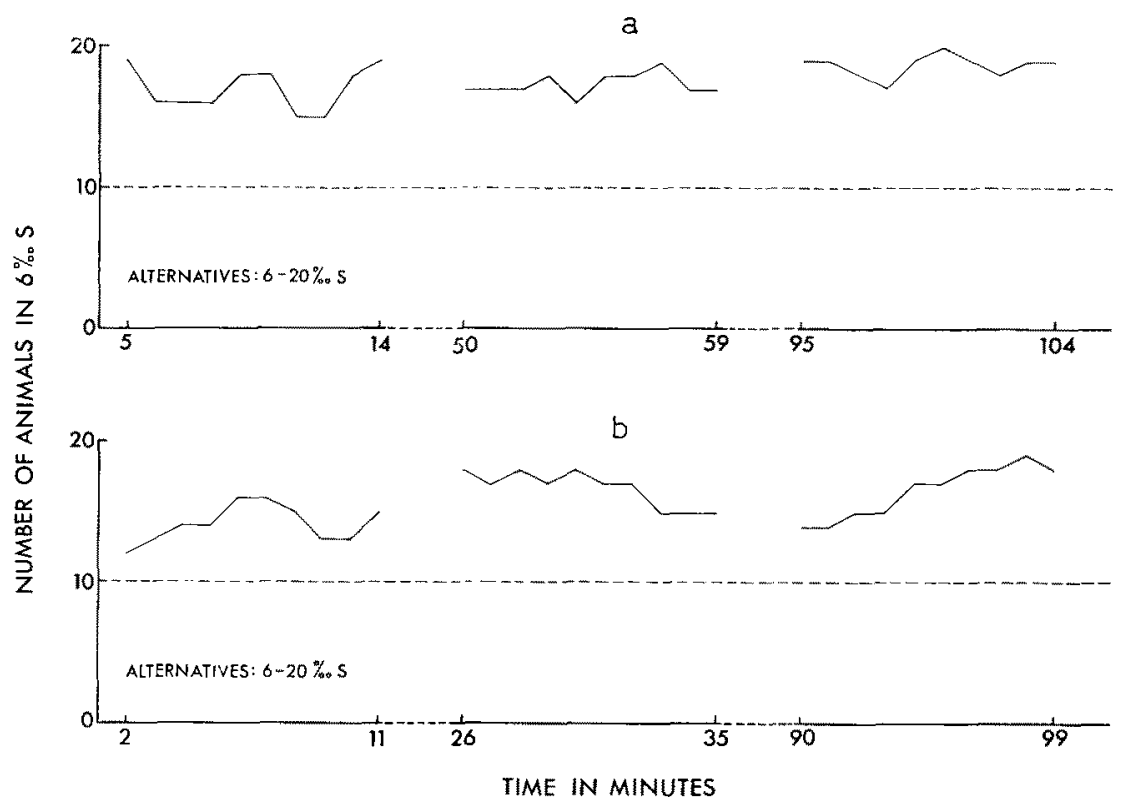

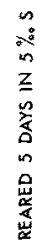

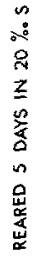

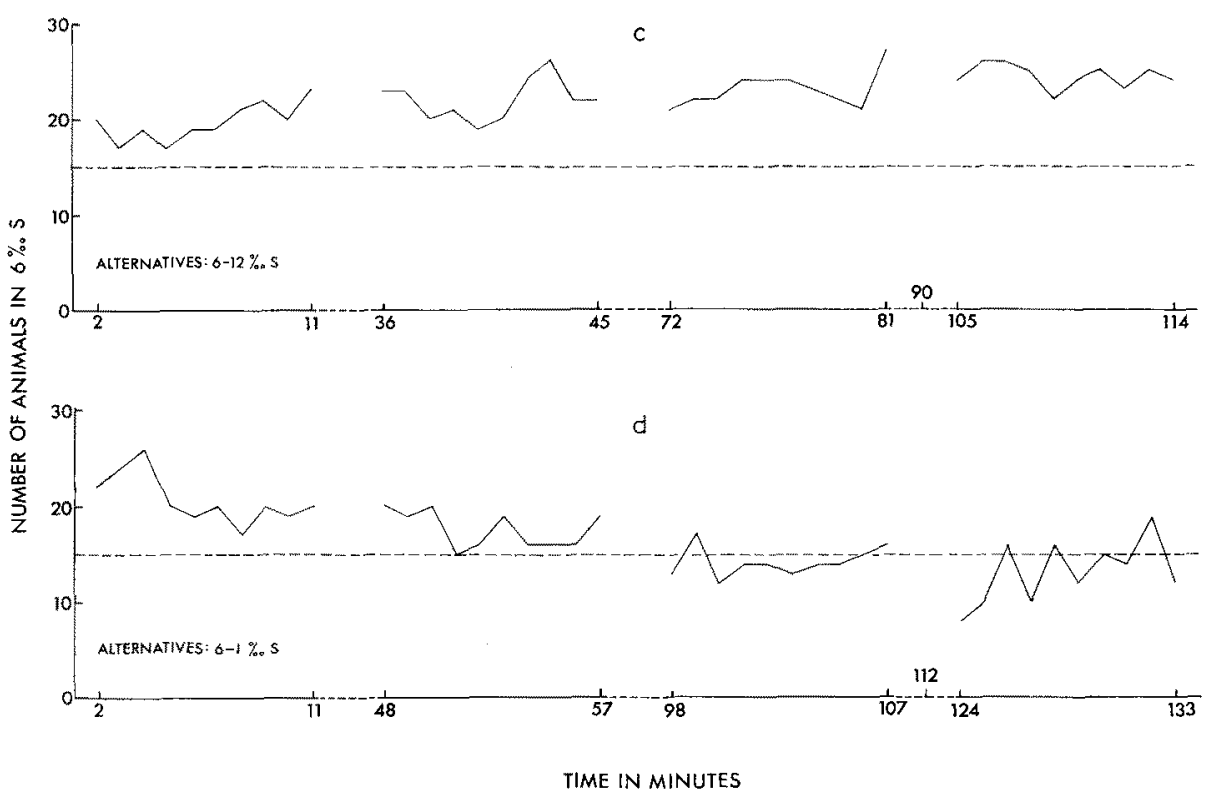

Fig. 8: Salinity alternative tests with Heterocypris salinus at 20-6\% after rearing in 2 different salinities, $\mathrm{n}=20$, and $12-6 \%$ and $6-1 \%, \mathrm{n}=30$. Inversion of alternatives after 90 resp. 112 minutes in the later 2 experiments 


\section{SUMMARY}

1. The relations between environment and fauna of rockpools are briefly discussed on the basis of information available in literature.

2. The necessity of combining field studies and laboratory experiments, as well as the need to know the extreme physico-chemical values of the environment for pertinent experimentation, is stressed.

3. Rockpool organisms are exposed to extreme conditions and diurnal fluctuation of salinity, temperature, $\mathrm{pH}$, oxygen concentration and illuminance; with the exception of salinity, all these factors vary greatly especially during a sunny day.

4. Many rockpool organisms exhibit diurnal vertical migrations; this is demonstrated quantitatively for the ostracod Heterocypris salinus BraDY, which is found in the shallow parts of the pools at night and in the deep parts during the daytime.

5. In laboratory experiments $H$. salinus is shown to be negatively phototactic.

6. H. salinus survives better in hypo- than in hyperoxygenated (or in $100 \%$ aerated) water but does not respond to alternatives offering hypo- and hypersaturation.

7. H. salinus shows a well defined reaction to different temperatures with a preference for $15^{\circ} \mathrm{C}$ when the alternative is $22^{\circ} \mathrm{C}$.

8. The investigated populations of $H$. salinus and Gammarus duebeni exhibit definite preferences for the most common rockpool salinity, $6 \%$, which is also found in the surrounding sea.

9. The possible influences of light, oxygen, carbon dioxide and temperature combinations and variations on the diurnal distribution of rockpool organisms are discussed.

\section{LITERATURE CITED}

Ambler, M. P. \& Chapman, V. J., 1950. A quantitative study of some factors affecting tide pools. Trans. R. Soc. N. Z. 78, 394-409.

BIEBL, R., 1937. Okologische und zellphysiologische Studien an Rotalgen der englischen Südküste. Beib. bot. Zbl. 57 (A 3), 381-424.

DAvy DE Virville, A., 1934-1935. Recherches écologiques de la flore des flaques du littoral de l'océan Atlantique et de la Manche. Revue gén. Bot. 46, 552-557; 705-721. 47, 26-43; 96-114; 160-177; 230-243; 308-323.

Feldman, J. \& Davy de Virville, A., 1933. Les conditions physiques et la végétation des flaques littorales de la côte des Albères. Revue gén. Bot. 45 (540), 621-654.

Fisher, E., 1929. Recherches de bionomie et l'océanographie littorales sur la Rance et le littoral de la Manche. Annls Inst. océanogr. 5 (3), 201-429.

Fox, H. M. \& TAyLor, A. E. R., 1955. The tolerance of oxygen by aquatic invertebrates. Proc. R. Soc. (B) 143, 214-225.

GANNING, B., 1966. Short time fluctuations of the microfauna in a rockpool in the northern Baltic proper. Veröff. Inst. Meeresforsch. Bremerh. (Sonderbd) 2, 149-154.

- \& WulfF, F., 1966. A chamber for offering alternative conditions to small motile aquatic animals. Ophelia 3, 151-160.

Gersbacher, W. M. \& Denison, M., 1930. Experiments with animals in tide pools. Publs Puget Sound mar. biol. Stn 7, 209-215.

IgARASHr, S., 1959. On the relationship between the environmental conditions of tide pool and the Tigriopus population. Bull. biol. Stn Asamusbi 9 (4), 167-171. 
- 1960. On the relationship between sex ratio and salinity as a regulator of growth speed in Tigriopus japonicus Mori. Bull. biol. Stn Asamushi 10 (2), 103-108.

Issel, R., 1914. Vita latente per concentrazione dell'acqua (anabiosi osmotica) e biologia delle pozze di scogliera. Mitt. zool Stn. Neapel 22 (7) 191-254.

JaNsson, B.-O., 1962. Salinity resistance and salinity preference of two oligochaetes Aktedrilus monospermatecus, KNÖLLNER and Marionina preclitellochaeta $n$. sp. from the interstitial fauna of marine sandy beaches. Oikos 13, 293-305.

KINNE, O., 1952. Zur Biologie und Physiologie von Gammarus duebeni, LinLJ., 5. Untersuchungen über Blutkonzentration, Herzfrequenz und Atmung. Kieler Meeresforsch. 9, 134-150.

- 1959. Ecological data on the amphipod Gammarus duebeni. A monograph. Veröff. Inst. Meeresforsch. Bremerh. 6, 177-202.

KLIE, W., 1938. Ostracoda, Muschelkrebse. Tierwelt Dtl. 34 (3), 1-230.

LAGERSPETZ, K., 1955. Physiological studies on the brackish water tolerance of some species of Daphnia. Archom Soc. zool.-bot. fenn. Vanamo 9 (Suppl.), 138-143.

- 1959. The brackish-water tolerance of some freshwater crustaceans. Verh. int. Verein. theor. angew. Limnol. 13, 718-721.

LAMI, R., 1941. Sur la flore de certaines cuvettes ombreuses de la zone intercotidale supérieure. Bull. Lab. marit. Dinard 23, 53-69.

LEGENDRE, R., 1923. Variations de concentration des ions hydrogènes de l'eau des mares supralittorales à Harpacticus fulvus. C. r. Séanc. Soc. Biol. 89, 722-724.

- 1930. Sur les limites des variations du milieu marin compatibles avec la vie d'Harpacticus fulvus. C. r. Seanc. Soc. Biol. 105, 264-266.

LindBERG, H., 1944. OKologisch-Geographische Untersuchungen zur Insektenfauna der Felsentümpel an den Küsten Finnlands. Acta zool. fenn. 41, 1-178.

Mancy, K. H., Okun, D. A. \& Reilley, C. N., 1962. A galvanic cell oxygen analyzer. J. electroanal. Chem. 4, 65-92.

Matutani, K., 1961. Studies on the heat resistance of Tigriopus japonicus. Publ. Seto mar. biol. Lab. 9 (2), 379-411.

MCGregor, D. D., 1965. Physical ecology of some New Zealand supralittoral pools. Hydrobiologia 25, 277-284.

NAYLOR, E. \& SLINN, D. J., 1958. Observations on the ecology of some brackish water organisms in pools at Scarlett Point, Isle of Man. J. Anim. Ecol. 27 (1), 15-25.

NoRDENSKIöLd, E., 1900. Beiträge zur Kenntniss des Thierlebens in Wassersammlungen von wechselndem Salzgehalt. Övers. K. Vetensk. Akad. Förh. 9, 1115-1127.

Pyefinch, K. A., 1943. The intertidal ecology of Bardsey Island, North Wales, with special reference to the recolonization of rock surfaces, and the rock-pool environment. J. Anim. Ecol. 12 (2), 82-108.

Ranade, M. R., 1957. Observations on the resistance of Tigriopus fulvus Fisher to changes in temperature and salinity. J. mar. biol. Ass. U. K. 36, 115-119.

ReEs, G., 1941. The resistance of the flatworm Monocelis fusca to changes in temperature and salinity under natural and experimental conditions. J. Anim. Ecol. 10 (1), 121-145.

REUTER, J., 1961. Einige faunistische und ökologische Beobachtungen über Felsentümpel-Ziliaten. Acta. zool. fenn. 99, 1-42.

Stephenson, T. A., Zoond, A. \& Eyre, J., 1934. The liberation and utilization of oxygen by the population of rock-pools. J. exp. Biol. 11, 162-172.

UBRIG, H., 1952. Der Einfluß von Sauerstoff und Kohlendioxyd auf die taktischen Bewegungen einiger Wassertiere. Z. vergl. Physiol. 34, 479-507.

VACELET, E., 1959. Étude physico-chemique des flaques supralittorales à salinité variable. Relations avec les peuplements. Recl Trav. Stn. mar. Endoume 29 (17), 5-88.

- 1963. La richesse en elements nutritifs en période estivale dans les cuvettes à salinité variable. Recl Trav. Stn mar. Endoume 29 (44), 11-19. 


\section{Discussion following the paper by GANNING}

Amaniev: Demande, quelles sont les espèces de la macrofaune associées dans les flaques décrites, et si les migrations nycthémèrales ont été observés parmi les représentants de la macrofaune.

GANNING: The only macroscopical animals found in this type of rockpool are Gasterosteus actuleatus, Gammarus duebeni, Limnea peregra, and sometimes also some water bugs. The two first mentioned are predators on the ostracod Heterocypris salinus. All these observed macroscopic animals exhibit diurnal movements. They are found in surface waters during the night, the amphipod and the gastropod often above the waterline, and move down during the day.

SCHLIEPER: Have some other species or genera of rockpool ostracods from more marine pools been studied?

GanNING: There is just one more species known of Heterocypris, namely, $H$, incongruens, from almost fresh water pools. $H$. incongruens has been studied, but because of time limits this fact has not been mentioned here. Other genera from marine pools and more marine populations of $H$. salinus have not yet been studied, but I hope they soon will be. 